\title{
Memories From The Communist World
}

MEMÓRIAS DO MUNDO COMMUNISTA

Nicolae Manolescu

Universidade de Bucareste

Bucareste, Romênia

Keywords: Literary life; Romania; socialism; literature and society.

Palavras-chave: Vida literária; Romênia; socialismo; literatura e sociedade.

Mots-clés: Vie littéraire; Roumanie; le socialisme; la littérature la société.

\begin{abstract}
In this essay the renowned critic Nicolae Manolescu presents a memoir of his literary experiences since his schooldays until the post-socialist period in Romania. Noteworthy is the lack of linearity in the narrative, which questions several literary stereotypes.
\end{abstract}

\section{Resumo}

Neste ensaio o renomado crítico Nicolae Manolescu apresenta um painel de suas experiências literárias desde os tempos de escola até o período pós-socialista na Romênia. Digna de nota é a falta de linearidade da narrativa, que questiona vários estereótipos literários.

\section{Résumé}

Dans cet essai, le célèbre critique Nicolae Manolescu présente une chronique de ses expériences littéraires depuis ses années d'école jusqu'à la période post-socialiste en Roumanie. Il convient de noter l'absence de linéarité dans le récit, qui remet en cause plusieurs stéréotypes littéraires.
The Romanian public opinion of today has a contradictory attitude regarding the communist world. On the one hand, quite a lot of people have not forgoten the difficulties of life, the humiliations, the short and dreary television programmes, the scant information in the newspapers, the lack of freedom of speech, the abuse of the Securitate secret police, or the revolting cult of the personality of Nicolae Ceauşescu. On the other hand, there are also enough (according to a debatable survey, $47 \%$ !) nostalgiacs, who remember their holidays at the seaside or in the mountains and, from time to time, in the neighbouring communist countries - which they no longer can afford -, their small wages, which were nonetheless as stable as their state jobs, their cheap cars or homes bought in installments, their equally insignificant rents and expenses on utilities in their drab blocks of flats, the relative equality of incomes, which created the illusion of the equality of rights. Certainly, the unhappiness or nostalgias depend on one's intellectual level. This doesn't 
mean that the intellect confers any privilege: yet, it is obvious that we aren't all unhappy or nostalgic for exactly the same reasons. Our unhappiness or nostalgias have different causes and natures. Some have a greater sensitivity towards the same phenomenon than others. Democracy is not equally essential for everybody. The lack of the freedom of speech does not matter for all. Not even the daily nuisances, the cold homes, the abominable public transport of the past regime carry the same weight for everybody. And with respect to the Securitate secret police, to the abusive arrests and indictments, only my generation still preserves accurate memories and unhealed traumas. The following generations were confronted with a greater "discretion" of the repressive measures. One family in five had, in the 1950s, members or relatives in jail or labour camps. In the 1980s, only those who listened to radio "Free Europe" knew about the existence of the psychiatric wards where the dissidents were confined. The quantity and the circulation of information give birth to different social psychologies. And to different reactions, as well. The inertia is not one and the same in all cases. We have those who are dissatisfied with communism and the nostalgiacs of communism, because the common past is weighed with different measures.

It is honest to say from the very beginning that I cannot pretend that my memories of the communist world should be shared by everybody. Especially as the communist world in which I lived is, to a great extent, the literary world. They will surely not be shared even by all those in my generation. This is not necessarily due to the fact that my memories might be unique. On the contrary, they are common. With some differences, which are due to the fact that I was lucky to work in a field which allowed me more freedom of movement than others, both factually, and figuratively. In those years, for instance, I travelled abroad. This is a privilege which writers enjoyed, at least from a given time onwards. I do not feel guilty about that, because I do not believe that privileges are bad in themselves, what's bad is to take advantage of them in a wrong way. A privilege is a duty that society owes to its elites. I travelled to France, Germany, Italy, to the Netherlands, to the U.S. As to the freedom of movement, figuratively, let me say that I managed, for instance, not to join the Romanian Communist Party. Had I been an engineer, like my brother, in a state factory, I would have probably also become an ordinary member of the single party. My 
profession as a writer also helped me this time. It is another privilege. I am confessing these things so that it shouldn't be inferred that the freedom of movement which I enjoyed is automatically linked to personal merits. I am not being falsely modest, but I am totally aware that to a greater or lesser extent, that respective freedom of movement also depended on me and on us, in general. Let it not be understood, however, that I was more distinguished than others. During one of the first live television shows after the 1989 December Revolution in Romania, somebody praised me for having been a dissident. I replied that, unfortunately, I had not been a dissident, first of all to my own regret. I had resisted, as much as I could, the temptations of a regime which commended its intellectuals especially if they sealed the pact with the devil. After some time, the writer Radu Cosaşu, who had watched the televised show, told me that few would have had the strength to admit publicly, especially in those moments of euphoria, such a thing. Many careers of dissidents were built then, post-factum. Cosaşu's remark made me feel much more comfortable than that of the reporter. I am also aware of the fact that my memories might be construed, by some of those who will read them, as ambiguous. The ambiguity is inevitable, as I will explain further on. I am no visceral anticommunist, like so many after 1989. And, even less so, a nostalgiac. I consider myself, perhaps without the appropriate modesty, a lucid anti-communist. In other words, I try not to benevolently reconsider the former regime, but to explain to myself how it was possible that outstanding intellectuals, both in my country and elsewhere, should have fallen victims to the sirens of communism. Why did they not seal their ears with wax, like Ulysses? I asked the question to two writers, Virgil Ierunca, a Trotskyite in the 1940s, before he emigrated, and Paul Georgescu, a communist when the party was outlawed, who had fabricated himself a death sentence under the regime of Ion Antonescu - the Fascist leader of Romania during the WWII -, which he had later blamed on a hero from his novel Before Silence. Their answer was the same: between fascism and communism, they had chosen the latter. OK, I said, you had heard about the Holocaust, but hadn't you heard about the Gulag? They had also heard about the Gulag, but due to reasons known only to their generation, they had preferred the Gulag to the Holocaust. Might it have been less embarrassing? To left-leaning people as both were, it might have been somewhat understandable. 
But why hadn't they heard about democracy, an infinitely preferable middle path? The latter question did not remain unanswered either: democracy seemed compromised to them. "As it seemed to Nae Ionescu!," I replied, in my turn, not without irony.

I have read, in the years after 1989, many criticisms of democracy. Like any middle-of-the-road paths, it seems that democracy is, to quote from Adam Michnik, grey. People, especially the young, like strong colours. In recent years, a few have teamed up and have published books about communism. None of them were older than 18 when communism collapsed. None of them can claim that in their family they were talking freely, at the end of the 1980s, about the reality at home, or about Ceauşescu. I am not as concerned about the fact that they speak of things they know nothing about, not even from hearsay, as about the fact that they are all left-leaning. Some are even positioned left of the left, where Maoism is blooming again. After a time when it had seemed that the far right was recovering the ground lost under communism, the time has come, indeed, when not the neo-legionaries, but the neo-communists are loud-mouthed. The place of the septuagenarian national-communist Dan Zamfirescu has been taken by the young communist philosopher Alex Cistelecan. None of the two is lacking in reason or education, which is worrying me most. Even a man as lucid as Andrei Cornea thinks that a consistent left is a good thing, especially as Romania has always been accused of having had an intellectually bright right, and an ideologically-challenged left. Isn't it yet obvious that the scenario of the 1940 s is being repeated? That the abhorrence of fascism, instead of leading us towards democracy, is throwing us straight into the arms of neo-communism? And that, not before having drunk from the poisoned chalice of Marxism-Leninism, but after we saw what Stalinism and the Cultural Revolution are capable of.

The ambiguity I was talking about is the only honest attitude towards the past. There is a great difference between living in one regime and judging it from a historical point of view. First of all, we live our times without a distance, sometimes critically, in any way, subjectively, but too closely to be able to claim that we have the appropriate discernment. In history, a judgment is, more

\footnotetext{
${ }^{1}$ A Romanian philosopher, logician, mathematician, professor and journalist. Near the end of his career, he became known for his anti-Semitism and devotion to far-right politics, in the years leading up to WWII.
} 
often than not, subsequent. I was exactly 50 years old in 1989 . I was thinking, not without ingenuity, that, since I had lived in a communist regime until that age, I knew it quite well and in the tiniest details. As time went by, that naive assurance has dwindled. I have had plenty of opportunities to doubt it. What I had fully believed in at a given time proved false. And many a thing proved to be mere thinking stereotypes I am not proud of at all.

A banal happening has revealed to me such an unfortunate stereotype. Upon my mother's death, I recovered several notebooks with my adolescent writings, which I had thought lost. They were poems or prose writings from the early 1950s. An age steeped in my memory as one of acute proletkultism and dominated by the proletarian internationalism of the Kominform. Actually, my modest attempts at poetry, inspired by Vasile Alecsandri in his patriotic lyrics, and at prose, by Mihail Sadoveanu, in his historical novels, are reading now as-nationally-as-possible compositions in their intimate substance. Although the idea that a word like nation was prohibited was deeply rooted in my mind, and The Story Of My Nation, which I had read in my early childhood, could not have a print rerun because of its title, with people preferred to it, here I was, using, with the thrills of a Sadoveanu-imitator, the word nation, which shook my preconceived idea and raised a big question mark about its truth. I had, among others, written the draft of a novel about Dimitrie Cantemir (an eighteenth century Moldovan Prince, a true Renaissance figure), with a crystal-clear national undertone, and one quotation from the author of The Description of Moldavia, which I had proposed to the colleagues from my generation of the "Gheorghe Lazăr" high school from Sibiu, as a motto for the picture of our graduation class, which was hanging not long ago, and might still be hanging, on the wall of the hall leading to the headmaster's office, reads: "There can be no peace for the soul until it finds truth, however gruelling finding it might be." I cannot vouch for the accuracy of its reproduction, but this is certainly the gist of it. In 1956, the quotation was not really politically correct. And about Cantemir, we had been taught to believe that his thinking was class-oriented, as with all the ruling princes.

For quite a long while, we didn't have literature textbooks. We were learning from the so-called "Provisional Theses," two brochures of the history of literature, the first I laid my hands on. For a long time, my idea was that they were awefully biased and 
incomplete. Even the literary critic Tudor Vianu had slaughtered the history of Romanian literature in a French language text published by UNESCO in 1956. What could one expect from some anonymous theses from the beginning of that decade? True, they were limited to the older period, less affected by proletkultism, which had saved them from the claws of the censorship to a somewhat extent. It is not a mere accident which brought them to my eyes when I was working on The Critical History of Romanian Literature. Upon re-reading them, I noticed that they contained an enormous amount of quite accurate information, more than some of the present-day high-school textbooks. I remembered that it was there that I had learned by heart the Latin titles of Cantemir's works, which I haven't forgotten even to date, as well as most of what I knew about our Mediaeval literature. Students were being well schooled, therefore, despite the almost prevailing impression of the later years. We were lucky that the theses included only few interpretations, unlike the many found in the forewords to the volumes of the chroniclers, which were also reprinted in the 1950s. Another proof that the proletarian internationalism never had with us the power of thwarting the study of the national works. No censorship, even at the peak of the cure of Slavicism, succeeded in eliminating the memorable assertion from Grigore Ureche's chronicle dating from the seventeenth century: "We are descended from Rome." And my Romanian teachers were expecting us to read the complete works of the major writers, who were not all included in the curriculum. In 1954, when I was in the 9th grade, I had to prepare for recapitulation not only the Popular Short Stories by the classical novelist Ioan Slavici, or his novel Mara, but also his plays, which are not mentioned today even in the academic curricula. It is true that, in 1956, when I was a freshman, Professor Ion Vitner was concluding his special course in Mihail Eminescu ${ }^{2}$ at the middle of the poem Emperor and Proletary, where the speech of the proletary was ending, deeming that that was the only progressive part, yet the same Ion Vitner was proposing, only a few years later, a special course of literary criticism, which allowed us to learn for the first time about Sainte-Beuve and Albert Thibaudet. As their books were not available in the library of our Faculty, or were not loaned to the students, the professor was bringing them from home

\footnotetext{
${ }^{2}$ The most important Romanian poet of the nineteenth century.
} 
and was offering them to us. For the exam, he allowed us to choose the critic we wanted to speak about. I forgot to mention that, as a precautionary measure, he had also dwelt in his course with Belinsky, Dobrolyubov and Chernyshevsky. I chose Thibaudet. He asked me to motivate my option. I had the cheek to tell him that I liked Thibaudet because he was not an ideologist like the three Russian luminaries of the 19th century, but a literary critic, a profession I was hoping also to espouse myself in the future. I seem to have persuaded him: he listened to me until the end and then gave me the top mark. Hence, I draw the conclusion that neither the high school, nor the university were, not even in the bleakest times, as bad as many, including myself, have the tendency to believe, based on a treacherous memory, entrapped by clichés. On the other hand, I am not forgetting that, in the same years, I have not heard either in my high school, or in the university, about Titu Maiorescu, Eugen Lovinescu, Lucian Blaga, Hortensia Papadat-Bengescu and so many other great writers, especially the modern ones, on which the censorship was voluptuously unleashed. One can only escape ambiguity at the price of truth, relative as it might be.

What do I remember about the newly-communist Romania of my teens? There is a deep rift separating my childhood from my adolescence: my parents' arrest, in the night of St. Mary, August 14 to 15,1952 . I have told the story too many times to repeat it again. The fact is that, during a single night, the child who was to turn 13 three months later, became an adolescent. The next day, nothing was as before. The place of my parents, aged 40-50, in the prime of their life, was taken by my maternal grandparents, who seemed to me very old, although later on, I realised that my grandmother was only 65 and my grandfather was one year younger than I am today. I changed town, neighbours, school, schoolmates. Gone were my holidays at Sibiel, in the mountains, from the previous summers, where I had used to spend three weeks every year, in the wooden huts of the villagers who had there plots of hay and pastures for the barren cows. People were not yet going to the seaside for holidays. I went only once, in 1951, to Costineşti, through the teachers' trade union. We all slept, children and parents, in a classroom, on the floor, on mattresses made of sheets filled with straw and sown on the rims. I was most interested not by the sea, which has never said much to me, but by the anatomic peculiarities of the ladies and young girls who were shunning my gaze in vain, when 
they were dressing in the morning or undressing at night. We didn't get any sexual education at that time, neither from the family, nor in school. It was not from modesty, but from the lack of tradition: an old state of things made it that there was no talking about sex. Neither was private hygiene (compulsory after a certain age) part of the views of our parents or educators, who thought it enough to check whether we had dirt under our fingernails. Speaking of education and hygiene: during one of my holidays spent with my maternal grandparents, I faced a delicate problem. I had to consult my grandmother. After I had pulled down my pants, my face as red as a lobster, she looked at the respective spot for a while, without understanding better than I the cause for my persistent itching, and she appealed to her sister-in-law, who was just as unsuccessful in finding an explanation. Although she was awfully embarrassed by her own lack of experience, my grandmother quickly recovered her sense of irony and showed her amazement by asking her sisterin-law a question which she probably thought I would not notice, but which has stuck in my brain: "Well, Athena, haven't you ever seen Gogore's dickie?” To which Athena - that's how Gogore's, actually, Grigore's, wife was named - candidly replied: "I have never seen it." She had borne him two children, but had never seen his dickie. Those were the days. My grandmother's sister-in-law was by no means an exception. Nor are the preteens of today similar to the preteen I was at 12. I had had several amitiées amoureuses, but not more, and not from the prejudice that I would have sex for the first time only when I got married, but because few were those who started their sexual life as early as the teenagers, boys or girls, of today. I don't think I knew the meaning of virginity. The idea was simply not bothering me at all. I lacked, we lacked, the provocations: there was no television, the movies were heroic, not erotic, the word pornography had not made to the dictionaries, and the family and the school considered sex a taboo.

Let me return to my childhood holidays. I would spend them with my maternal grandparents in Râmnicu Vâlcea or with my grandmother from Sibiel. These holidays were the only ones that our parents could offer us. In Rm. Vâlcea, we would play, my brother and I, in the two yards or in the garden, all big and full of wonders. The surrounding hills did not attract me after the holidays spent at Sibiel, in the mountains. There, indeed, it was something else. Besides the huts of the farmers, consisting of a single small 
room, a bedroom-cum-kitchen, there were two real holiday houses, which were quite rare in those days. The most imposing belonged to Andrei Oţetea, the historian, my father's first cousin. Two huge rooms, with terra-cotta stoves, separated by a kind of refectory, like in a monastery, a summer kitchen, a yard, all enclosed in by a tall wooden fence, a true fortress. From a neighbouring mound of earth, named cucă, we watched at night the lights of Sibiu, the most beautiful show of my childhood. We brought the food from the village, in woolen bags woven in the region, saddled on the back of a horse. We had a problem with bread, which was sold on daily coupons, in Sibiu. Although the oven in the yard of the house in Sibiel, where my father was born, lasted for many years after, my grandmother had not baked bread for a long time, due to the lack of wheat. My father had arranged with a saleswoman from our district, in exchange for several ration coupons that my father gave, from time to time, to a saleswoman from our district, for her own use - he had arranged with her to give us a whole week's ration. Even that way, he had to climb down from the mountain and take the train to Sibiu about twice during the holidays. The bread was dark and it was getting dryer, but the taste had remained unforgettable. What else could we have eaten? The meat was getting rare, but there was plenty of milk and cheese. We bought them from the shepherds. There were no vegetables in Sibiel, a mountain village, but there was no shortage of fruit, apples and plums. And, God, what a beautiful weather we enjoyed all the summer and how careless about the times we were! We would pay dearly for this absence from the world that was being built around us, day by day, hour by hour and in mass proportions, as Lenin had said once, referring to something else, Lenin of whom neither we, the children, nor our parents, had heard of yet, used as we were, like most in those times, with other rythms of life than those of history and, even less so, with those of politics.

It took only one night for this wonderful chapter in our life to end. Those who speak of stability during the communist regime have forgotten the arrests which took us unawares and the upheavals they brought to the destiny of many families, the nationalisations and impounding of assets, which threw people out of their homes and forced them to live heaped up with unknown people who had suffered the same ordeal. Needless to say that the measure was political and artificial: the industrialisation process and 
the massive migration of farmers to towns had not started. In the early 1950s, another three families were living in the Rm. Vâlcea house, where I was born and where my mother and her brothers had been born. We had been left without a bathroom, which now belonged to another family, following the arbitrary partition of the space. We were using an outdoor can, without running water, similar to those in the countryside, at Sibiel, for instance. That may be why it didn't seem uncomfortable to me, unlike my grandparents, hopeless townspeople, for whom getting dressed, in the winter, at night, climbing down the stairs, crossing the yard, in the cold or the rain, didn't hold much appeal. However, I do not remember them complaining. I was lucky that my closest relatives showed a remarkable stoicism in the most demanding circumstances. A life lesson that was useful to me. We slept in the only room which had been allotted to us, in our own house, all four of us, in two beds, we washed in a basin in the morning, with water heated on the boiler of the terra-cotta stove, we went to school from there, we spent the evenings there, at the light of gas lamps, when, almost always, the electric plant at Zăvoi broke down, we did our homework there, it is there that, several months later, the newsroom and printing house, so to speak, of the magazine "The Family" would operate, the magazine I wrote myself and would read, every Saturday evening, from the first to the last page, to my grandparents, who were joined by my grandmother's sister, the grandaunt I have often mentioned. The room was awash with the smell of dry apple peel for tea, a commodity which had vanished from the shops, and, if I had not had, moment after moment, our parents in my mind, everything would have been almost idyllic. The idyll, I feel compelled to state it, has nothing to do with wealth or poverty, but with simplicity. And it is a luxury of the mind.

About my parents, I knew nothing, neither where they were, nor when they would return, not even if they were still alive and would be back. Little did I hear about them in the two years and a half, while my father was gone, and in the three years of my mother's absence. In all those years, we got two postcards, one from each of them. Mother was letting us know the exact date when we would be allowed to visit her in prison, where we went, my brother and I, only us, as first-degree relatives, with no one else allowed to go. The brief letter also contained a word which grandmother decyphered with the magnifying glass. Among the things mother was asking 
for, there was also pain d'épice. Gingerbread! I can't imagine how the French phrase had escaped the censorship. Grandmother baked the gingerbread and sent it to her. I must tell you that grandmother was a great cook, she had her own recipes, unlike mother, who cooked only if she had no choice and who often got lost in the recipe book inherited from grandmother. I think she wouldn't have been able to bake that gingerbread. Father's postcard confused us all. He was giving my brother his leather briefcase, which he had carried for thirty two years to the schools where he had taught, and I was getting his Omega pocket watch he had never parted with before his arrest. We interpreted the gifts as a bad omen: he was sick and he suspected he was going to die, and as he could not write that in a letter from jail, he was letting us know it allusively. Both I and my brother categorically refused to get the presents poisoned by dark thoughts, although I was dying of pleasure to wear the watch. I don't know if the briefcase survived the weekly shuttle from Sibiu to Hosman, by Decauville train, with which father concluded his career six years after his exit from jail and when there was no longer a teaching job in town for a former convict. The watch is now in my possession. It still works, but I have to wind it several times a day, as the coil has shortened from successive repairs. Father came back home in February 1954. I happened to be at the window of the room which overlooked the front garden and the street. I saw a man wearing a shabby overcoat, who was pushing the big gate to let in a small pushcart, which was too wide to squeeze through the small gate. I din not recognize my father right away. When I came to my senses and dashed out on the stairs, father had already walked up to the yard behind the house and was shouting in a hoarse voice: "Good people, are you glad to welcome me?" Even now, nearly six decades after, I cannot recollect that scene without bursting into tears. Mother's return was less dramatic, because from Dumbrăveni, where she had been in jail for the last half year, she had to cross through Sibiu to get to Rm. Vâlcea, so that she let father know, I think, to fetch her, and they both came the following day. Grandfather had been informed and he warned us. He had been told by a phone operator, a woman, who lived in our house, whom father had called. I cannot fail to say one thing. For all the fear, people were not devoid of a sort of courage, and they showed solidarity with those stricken by fate. The phone operator I was referring to had also done us a good turn in the past. She was the 
one who told us in great secrecy, six months after mother's arrest, that she had inferred from a phone conversation she had intercepted unintentionally (it seems that the Securitate secret police itself could also, in the beginning, be listened to!) that the women convicts from the Rm. Vâlcea jail, including mother, would be driven by truck to Piteşti the same day at noon. Grandfather and I took up position on the Boulevard, where the convoy would inevitably drive by. Hiding behind a tree, we waited for hours. By dusk, the trucks showed up indeed. They had tarpaulin canvases which did not allow us to see inside, or those inside to look outside. Mother was surely in one or the other of the trucks, but we couldn't catch sight of her at all. I was awefully frustrated, like few times in my life. After all, I was 13 and I only wanted to see my mother for a few moments. The next summer, when we were allowed to visit her in jail, at Pipera, my brother and I were separated from mother by a wire fence. Mother asked the woman guard who patrolled nearby to let her clasp our hands. The woman guard threatened her that if she squeezed her hand through the fence, she would hit her. So that mother couldn't, not hug her children, but even touch their hands. I have often wondered, since, what they could have told or done to some, like the respective woman guard, to destroy any shred of compassion for the suffering of a mother separated from her children by three years of life and a wire fence. My frustration was not inconsequential. It brought about a rift, as I have said before. The communist doctrine had initially seemed quite convincing for a significant number of intellectuals, especially from the generations which had preceded mine. And it could also have been so for me. Fortunately, it hasn't been meant to be.

Here are two significant incidents. I was a child when the regime was installed and, until my parents were arrested, I don't remember having been aware of what was happening around. Children don't pay attention to things which don't concern them. In September 1949, I was delighted to tie the young pioneer's necktie around my neck, and I was happy to have been asked to recite one of my poems (everybody knew that I was writing poetry) for a rally in Verzelor Square in Sibiu, behind the Haller Bastion; I suppose it was for the celebration of the Great October Revolution, a day which was celebrated on November 7, that is, according to the new calendar. It was, of course, a patriotic poem. Not internationalist, but patriotic. I was describing the beauties of my 
country as seen from a train window. After the round of applause, I proudly opened the march, holding in my hand the cardboard roll from which I had read the poem. Flanked by two giants carrying flags (I forgot which ones, but one was surely that of the People's Republic of Romania), I crossed the town, watched by the throngs of people lining the pavements. It felt great. I missed by a whisker becoming an official poet. I was lucky, thank God, that my parents' arrest blocked my political rise. I became a political orphan. The phrase was coined by my physics teacher from the 9th grade at the "Nicolae Bălcescu" high school in Rm. Vâlcea, Paulina Covăsneanu, a friend of my mother's, who never called me to the blackboard in her class for one year, because, whenever she caught a glimpse of me, she would burst out in tears and would send me back to my desk. When her substitute in the 10th class graded me with a splendid "F" remarking that I knew, to quote her, absolutely nothing, Paulina forced her, with the entire teaching kin in the high school agape, to change my mark, as a proof of indulgence for my exceptional situation of political orphan. That was the occasion when Paulina Covăsneanu, her name be blessed, launched the daring formula. Nothing happened to her. Nobody ratted on her, although the entire school was abuzz. I defy anyone to claim, in my presence, that there were no brave people under communism and that everybody ratted.

Now, for the second incident. I was a second year university student in 1957 when, probably due to the fear of a scenario à l'hongroise, measures were taken in order to calm down the spirits. Among others, new elections were called for the $\mathrm{UTM}^{3}$ and the political commissars were replaced with the top students. That is how I became an UTM secretary for all the students in my academic year. My activity and that of the committee, made up of six girls, consisted in monthly activity reports. A closed vicious circle. I got the "Gheorghe Gheorghiu-Dej" scholarship worth 400 lei per month, including during the holidays, that is, twice as much as I was getting from home. In September 1958, it was revealed that I had not told the truth regarding my parents and I was expelled from the university. That is how I also lost the second chance of making a political career under communism. Later on, when I was invited to join the Romanian Communist Party, it was not hard to

${ }^{3}$ UTM - Working Youths' Union, which included students during the early years of communism in Romania. 
invoke antecedents which disqualified me politically and to turn it down. Leaving this half joke aside, it is clear that my destiny, like that of many of us, might have been different. I do not really have in mind serious and morally irrecoverable compromises, nor do I rule out the possibility that, should I have made them, I might have, however, ended them at a given moment, under the pressure of the events, or as the political life deteriorated. Yet, who can cross their hearts and hope to die that they would have resisted all the temptations until the end? Man's capacity to delude himself is infinite. That is why I said that it's one thing to live your times, and another to judge them. I was surprised to hear my voice recorded, for the first time, on a Tesla tape recorder: I did not recognise it. I was told that I heard it only with the external ear, not from inside with all the palate. That is the difference between how we "hear" our time when we have no perspective on it, and when there is a certain distance between it and us.

More than once have I recounted how I entered the public life, immediately after 1960, as a university tutor and literary critic. The age was one of opening, as they once said. The Romanian Communist Party was shedding, one after another, the scars of the Soviet occupation. This was the foremost concern of the Gheorghe Gheorghiu $\mathrm{Dej}^{4}$ team. The chance of my generation was the liberalisation of those years. A genuine, not a fake liberalisation, as many are claiming now, trying to diminish its importance. Even if the RCP itself was never bent on a true-blue ideological thaw; the circumstances compelled it to make some concessions to the intellectuals whom it needed once more, just like after 1945, as bearers of the political message. Ceauşescu's appointment as First-Secretary increased that necessity. Ceauşescu was quasi unknown outside the RCP and his legitimation before the Romanian society would also be the work of the intellectuals. One decade ago, I proposed as a subject for one of the "România literară Meetings" the very causes and nature of that liberalisation. For guest-speaker, I invited Paul Niculescu-Mizil, ${ }^{5}$ who had been one of its key players. To our surprise, actually half-surprise, we found out that the RCP had not been interested in the least in liberalising the culture in the 1960s. Its only concern had been to eliminate the Soviet domination. Lib-

\footnotetext{
${ }^{4}$ The leader of the Romanian Communist party between 1949-1964.

5 The former Chief of the Cultural Department of the Romanian Communist party.
} 
eralisation had been a collateral and unexpected bonus. Yet it had proved nearly irreversible, no matter how many times Ceauşescu would try, in 1971, in 1979 and so forth, to turn back the wheel of history. We had lived the liberalisation on our skin and we knew that it was not an illusion. Suffice it to remind that, from the midsixties on, a true literature could be published, sometimes very critical of the regime, and not only when it was referring to the obsessive decade, as the novelist Marin Preda called it, with a memorable expression, although the author had used it in a quite politicallycorrect sense. An outstanding theatrical movement was born. The music could return to its modern sources, which had been abandoned for decades. The fine arts regained the artistic dignity that had preceded communism.

Two preconceived and wrong ideas are linked to the cultural liberalisation of the 1960s. One is that it was only a pseudo-liberalisation. The idea can be accepted only if we consider the process from the angle of the communist officialdom, which feigned having forgotten about the control of culture. True, censorship closed only one eye, ready at any moment to reopen it again. Still, the artists knew how to take advantage to such an extent, that they prompted it into becoming indulgent. It is in the shadow of the latter word that the second preconceived idea blossomed, based on the confusion between an indulgence, wrested at the cost of huge efforts, and a good-willing tolerance, within certain limits, of the freedoms that culture was starting ever more often to take. The literary critic Eugen Negrici is the one who has insisted on this idea and has made the distinction, referring to the 7th-9th decades, between a tolerated and a dissident literature. In my opinion, the former term truly defines what E. Negrici designates with the second term. It is not the dissidents who wrote dissident works. The novelists Paul Goma, Bujor Nedelcovici, Norman Manea, Dorin Tudoran, among the exiled ones, the poet A.E. Baconski, among those who remained at home, wrote works against the regime, which were not and could not have been published at home. Of a different opinion, that is, dissidents, are precisely the writers who published their works at home and in the conditions of censorship, without sharing the communist ideology, and criticising the realities that the propaganda was extolling. The socio-political criticism of the novelists, poets and, to a lesser extent, playwrights first profited from the party criticism that Ceauşescu himself levelled against the errors of the 
Dej period, expanding then to the two decades of Ceauşescu rule. Augustin Buzura took the respective step from The Faces of Silence to The Voices of The Night, Dumitru Radu Popescu, from $F$ to The Royal Hunting Party. And I do not have in mind only epic parables, like The Crayfish by Alexandru Ivasiuc, but extremely tough realistic novels, even if some of them do not lack the elements of political parable. The incapacity of censorship to control and ban them was due to both political and cultural reasons. In the 1950s, censorship benefitted from precise ideological prerogatives. And it proved as effective as possible. Nothing escaped its vigilent eye. When the ideology itself lost its coherence, following the veering of the RCP doctrine towards the nationalistic right, especially after 1971, the criteria became not especially lax, as would follow from E. Negrici's thesis, but so contradictory - if we take into consideration the left-wing and internationalist essence of communism in its Stalinist beginnings - that they could no longer be applied. Literature, and not only it, could squeeze through the holes of the net which had been so forbidding before. It is totally wrong and, somewhat, lacking in honesty, to refuse the writers the merit of having fought for the freedom to write what and how they thought. They wrested that freedom by fighting tooth and nail. Censorship did not hand it over to them on a platter, but it yielded it, compelled by their strength and its weaknesses.

There is one other aspect which should be pointed out. The literature of the 1950s did not have an ally in literary criticism, but an enemy. Before the novels or the poetry of those years were dogmatic, a term which is being used quite seldom for a while now, the respective spirit was instilled by a criticism in itself dogmatic and less literary than ideological. A criticism disinteresed by anything else than the ideological purity of the literary works. A true watchdog of the Zhdanov-Doctrine dogmatism, ${ }^{6}$ imported from

\footnotetext{
${ }^{6}$ The Zhdanov Doctrine (also called Zhdanovism) was a Soviet cultural doctrine developed by the Central Committee secretary Andrei Zhdanov in 1946. It proposed that the world was divided into two camps: the "imperialistic," headed by the United States; and "democratic," headed by the Soviet Union. The main principle of the Zhdanov doctrine was often summarized by the phrase "The only conflict that is possible in Soviet culture is the conflict between good and best." Zhdanovism soon became a Soviet cultural policy, meaning that Soviet artists, writers and intelligentia in general had to conform to the party line in their creative works. Under this policy, artists who failed to comply with the government's wishes risked persecution.
} 
the Soviet Union and not even rendered autochtonous. Over the next decades, criticism was restored to its own rights. Instead of continuing to guard the dogma, it learned to guard art. It no longer served the policy of the RCP in the field of culture. It no longer practised any politics at all. It preferred a different option, which was to defend the cause of literature as art. Aestheticism took the place of the thematism from the previous decade. What one of my brightest and most cultivated students fails to understand today is that the aesthetism of the criticism practised by my generation was not a formalism, but a cult of values, just as the dogmatic literature was not content-based (it is precisely the real-life contents that censorship didn't need), but a cult of ideology. I am overcome by an irremediable sadness, to quote from the poet, ${ }^{7}$ when I see that I wasted my time and breath, and I wonder what the dummies might have understood, if even the young journalist Costi Rogozanu is accusing the critics of my generation of having shunned a politically open attitude to ensconce themselves in an ambiguous aestheticism. Isn't then literature itself defined by an indirect and ambiguous expressivity? Our aestheticism was not meant only to avoid an all-out war with the communist ideology. It tried to rehabilitate literature itself as an essentially aesthetic value, after the ideological compromise of the previous decade. The best proof that our option was correct is that the literature whose cause I have been advocating not only awakened from the dogmatic slumber, but also proved valuable and original. Although I have a bone to pick with Rogozanu because he disappointed me, I am displeased to see that, since he has turned into a political journalist inspired by the moment, he has lost the sense of the eternity of literature.

The saying goes that writers read their critics only when the latter write about their books. Yet, even in these conditions, the role of literary criticism was extraordinary, throughout the quarter of a century of Ceauşescu's dictatorship. I am not diminishing at all the role of the literature. However, I am convinced that few of the major works of the 1960s-1980s would have been published without the theoretical and practical backing of literary criticism. I have both examples and arguments. When Dinu Săraru was the manager of the Small Theatre in Bucharest, where some of the most remarkable shows were staged, he had a way of putting paid to cen-

7 The last line of the fifth "Autumn Rhapsody" by Romanian poet George Topârceanu. 
sorship by calling news conferences after the premiere, to which he invited, besides representatives of the Ministry of Culture, led by the notorious Tamara Dobrin, a number of drama or literary critics. I have attended several such news conferences, together with the theatre critic Valentin Silvestru and others. Our part was to defend the show from the circumstantial criticisms levelled by the officials. After Silvestru and myself declared that a show by Silviu Purcărete or Cătălina Buzoianu, for instance, was an awesome directing and acting performance, who could have had the cheek to criticise it? We then published in the magazines enthusiastic and, naturally, well-deserved reviews, which Dinu Săraru posted on a billboard at the entrance of the theatre. Some 15 years before, that had been the method used to try to save the performance of Lucian Pintilie's version of Gogol's The Government Inspector. One issue of the "România literară" magazine can vouch for that. A proof that Eugen Lovinescu ${ }^{8}$ was right that cultural evolutions are neither clear nor linear, is that, despite the worsening of the situation in the $1980 \mathrm{~s}$ and of the increasing pressures upon the literary circles, criticism could save more shows than in the early 1970s.

It is a great mistake to believe that the communist period was one and the same from 1948 until 1989. Or that we are speaking about a single censorship. And about the same literature. There have been different ages and they succeeded each other without a clear rule. More often than not, we saw turnarounds, leaps, progresses or regressions, both hard to explain, both then and now. I only know the early period of communism from other people's testimonies. I was a high-school or university student when socialist-realism was the compulsory creative method. About the aggressive proletkultism I know even less from personal experience. Yet, I could notice the progress made after the Geneva meeting between Eisenhower and Khrushchev in 1954. Not only that my parents were freed from jail at that time. But in 1954, "Gazeta literară" appeared, and, one year later, the "Contemporanul" became a very good cultural magazine under the leadership of the journalist George Ivaşcu. Another two years later, I was buying the "Caietele critice," in whose pages I met the name of Ion Negoiţescu, ${ }^{9}$ whom

\footnotetext{
${ }^{8}$ Eugen Lovinescu (1881-1943) was a Romanian modernist literary historian, literary critic, academic and novelist, who in 1919 established the Sburătorul literary club.

${ }^{9}$ Ion Negoiţescu was perhaps the most original and creative Romanian critic of
} 
I had been introduced to by the poet and director Radu Stanca (whose house in Sibiu, on Şaguna, then Lenin and then Şaguna Street again, I had visited many a time, and whose shows at the local theatre, with Angela Albani and Ion Besoiu in leading roles, I had attended several times). This prompted me into believing that I would also publish sometime in the future and inspired me the courage to show Savin Bratu what I had been writing - he had been my professor and now was the editor in chief of the only publishing house at that time. I was dreaming of becoming a prose writer. The meeting with Ivaşcu, after which I was born as a critic, had to wait for several more years. In 1958, I was unemployed. A step back for literature, if not also for the social life in general. And all of a sudden, in 1959 or 1960, Ivaşcu brought George Călinescu ${ }^{10}$ to the university, with an unpaid course, which was filling up the Odobescu amphitheatre. That was another turning point for my generation. Călinescu was not fascinating by what he was saying, as much as by how he was saying it. He taught me the most important thing in my intellectual life: the freedom of expression. Which was also a form of originality that I had never come upon before. I have many reasons not to share Călinescu's many opinions. However, there are at least just as many to consider him my master in the field of literary criticism. I also met him personally. Also thanks to Ivaşcu. I have visited him several times in his house on Vlădescu Street. I was listening to him agape. Sometimes he irritated me. For instance, when he taught Al. Săndulescu, a literary historian who had made his debut with a monograph of the poet G. Topârceanu, a lesson in opportunism. What our world needs, G. Călinescu shouted with his shrill voice, is not a dainty and frivolous small bourgeois like the author of the Original Parodies, but poets with wings as large as the ideals of the conquering socialism. Coming from Călinescu, such a reception could have been fatal for a critic's career. Al. Săndulescu weathered it well. It is also by that time that I was about to have my goose cooked. I had published in the "Contemporanul" two reviews of G. Călinescu's books, one about the second edition of his novel The Black Chest Of Drawers, the other about the collection of poems The Praise of Things. Apparently, neither had pleased my idol. A not very inspired turn

the post-World War II period.

${ }^{10}$ The most important literary critic of the twentieth century, expelled from his university chair in 1950 for so-called political reasons. 
of phrase had irritated him in the review of his volume of poetry: "the poet is making a case of Romanticism". The underscoring was, of course, absent from the review. I had actually meant to say that the poet was made, rather than born, a Romantic. Thank God that I hadn't said it! That would have upset him even more. The review of the novel triggered a reaction which I hadn't expected from him. Immediately after the review was published, he sent an outraged letter to George Ivaşcu, the director of the "Contemporanul," in which he was asking him who the fellow was that was signing the review, although I am certain that he knew very well. With his usual delicacy, Ivaşcu read to me only one part of the letter, whose contents was revealed to me one week later, when reading "The Chronicle of the Optimist”. Upon Ivaşcu's death, I didn't find the letter among his documents. I suppose that it was not very different from the article in the "Contemporanul". That one was perhaps a half-tone lower, because not even G. Călinescu could publish everything he cooked up in his mind at that time. In the letter, I was "a young critic," who doesn't know from direct experience the hyenous bourgeois-landowners' regime, and who had accused the author of The Black Chest of Drawers of exaggerating when he portrays it in dark colours and when he turns its main characters into caricatures. I had only written that the novel evinced a certain "propensity towards grandeur" (today I would prefer inclination), towards a thickened portraiture and towards the grotesque. That is, purely artistic observations, without any social and, all the less so, political connotation. I was so amazed that I asked Ivaşcu what I should conclude from all that story. "Hold your horses!," he said with a phrase of his I had heard before. "He is afraid that he might be suspected of not painting a sufficiently critical image of the past regime. In the first edition, that was the main objection of the censorship, which compelled him to make numerous re-writes under the surveillance of Ion Bănuţă, the director of ESPLA." ${ }^{11}$ I didn't know that the novel had posed problems for him five years before.

I still did not understand why such a personality as G. Călinescu was afraid. We were one generation apart. It seems that the distance was greater than I had guessed at that time, supposing that I had guessed anything. The sixth decade, which my gen-

\footnotetext{
${ }^{11}$ ESPLA (Editura de stat pentru literatura si arta), the publisher of literature and art in the 1950s became the major publisher of classical Romanian literature and criticism.
} 
eration had lived as a rarely directly involved spectator, and at any rate involved through the family, not the profession, had opened between us and the previous generations a chasm which was, in one way, deeper than those created between generations by World War I and World War II. Communism had affected the people's psychology and behaviour to a greater extent than any previous historical event. I have often noticed how deep was the mark on the writers who had lived their maturity years during the 60s. My generation had the absolutely unexpected chance of making our professional debut at a time of détente and change. Ilya Ehrenburg wrote a novel called The Thaw. Two decades before the perestroika and the glasnost, the widely-circulated Russian word had been ottepel, that is, thaw. Khrushchev's denunciation in 1956 of Stalin's crimes means, for all historians, the beginning of the end of communism. Even if the Hungarian Revolution, the invasion of Czechoslovakia or the arrest of the leaders of Solidarity seemed to have revived it later on. I have previously signalled E. Lovinescu's thesis about the lack of linearity of the cultural evolution. With us, a big Stalinist-type trial was staged against the intellectuals in 1958, and the most consistent attempt at a comeback to the socialist-realism doctrine occurred in 1971. Immediately after 1960 , the poets remembered the metaphor of the flowers rushing to produce buds, and which were taken unawares by the last wave of cold of the previous winter. The poet Nina Cassian published in one of her volumes a very suggestive poem on this subject. The evolution has proved, however, irreversible. Each assertive movement, although most of them were nipped in the bud at their time, laid another stone at the foundation of restoring democracy in our part of the world. My generation joined the professional life when the communist world was showing the first signs of illness. Not even the Cultural Revolution from Mao's China, with all its terrifying toughness, managed to provide a cure. Yet, were we aware, or not, of that? Or did we even guess it? I am not convinced. Not even when, in the 1980s, communism was no longer sick, but agonising, I am not sure that we thought differently: we placed all our hopes in the perestroika and glasnost, as the only possible path towards a communism with a human face. Despite all this welltempered optimism, the period after 1965 had seemed to us, at least for a while, to be heavenly. We were not naive, but we were considering what had been worst, not what could have been the 
best. How it could have been the worst we knew, how it might be better, that exceeded our experience. And, as long as we no longer felt the hand of censorship nearly at all, as long as the revaluation of the cultural heritage, in the language of the time, had begun, as long as translations were more numerous than ever and nobody was mentioning socialist-realism any longer, what more could we have wished for? The way in which we were received in literary life, with open arms and on the front door, instilled in us a psychology of pampered people. This would not be repeated with the next generation. And it is here that the psychological differences between us and them are rooted, even the differences in literary outlook, ours being more confident and committed to grand projects, theirs, more pessimistic and critically-destructive. Suffice it to compare - I am taking an almost random example -, the novels of Constantin Troiu to those of Mircea Nedelciu, to notice the difference in approaching reality. I am not speaking of value, which is indifferent in this case, and not even of success, which was enormous with the novelists of the 60s, and quite meager with those of the 80s, which tells, however, something important about the different motivation of the public interest. Published quickly and without the obstacles which had affected the psychology of our predecessors (and, as shown above, of our successors), we prevailed in the public consciousness, we entered the textbooks, and we even laid a hand in changing the textbooks and the curricula, compelling the cultural officialdom to consider us partners, which had never happened before, and which took them by surprise.

Following that victory, which they hadn't hoped for even themselves, the pampered people of the beginning of the cultural rebirth knew how to reap the due rewards. The most important thing consisted in imposing a parallel and different canon from the official one. The parallelism worked until the end. It was even more obvious in the 70 s, when protochronism emerged. After all, the real motivation of protochronism was not the defence and illustration of the national spirit, as claimed by its advocates, but of the party spirit. The proof that things were really that way was made, almost without realising it, by Katherine Verdery, an American interested in Romanian literature, in a book about protochronism.* She noticed that the articles which were favourable to protochronism were by far more numerous in that period than the critical ones, yet the number of favourable critics was smaller to that of the dis-

* (VERDERY, Katherine. National Ideology Under Socialism: Identity and Cultural Politics in Ceausescu's Romania, 1991, California University Press.) 
favourable ones, and, if we take into consideration those who really matter, the ratio is clearly disbalanced. To Katherine Verdery, the paradox could not be explained. It is, however, apparrent: censorship was letting through quite easily the favourable articles, yet it was often stopping the disfavourable ones. The unity of views, so dear to communism, would have been, indeed, threatened. The national interest was being claimed, whereas the party one was at stake. It is worth making an additional remark, which I hope will not be taken as exaggerated. In the battle against protochronism, we had an ally in the person of Ceauşescu himself. Moreover, we were fully aware of that, and we played our card cleverly. Our generation can proudly claim that it forced the officialdom to treat it with kid gloves, if not necessarily with fear, in the moment when it discovered that, while explicitely claiming its allegiance to the Ninth RCP Congress of the summer of 1965, it had become quasiinvulnerable. Was it not, actually, the outcome of the rift which Ceauşescu had proclaimed during the Congress, between the dogmatic period, tainted by abuse and crimes, and the golden age, which he was inaugurating himself? And who could have better illustrated it on a cultural and moral level, than this genuine literature, which even the fiercest foes of the regime from Radio "Free Europe" recognised as very valuable? A literature which was providing a much more credible propaganda to Ceauşescu's cultural policy than the direct one of the party writers. Obviously, Ceauşescu could not give up that panache. Still, not all the officials had his political cleverness and we feared them most, a Mihai Dulea, for instance, the politruc (political instructor) who was unanimously loathed. As for the party writers, they were too interested to benefit from the privileges not to try to control on their own the literary market, or with a better word, the ideological one. At the height of the protochronist delirium, they asked for Ceauşescu's permission to create another Writers' Union. The existing one, whose leadership had been, to a certain level, elected democratically, and which was dominated by writers who were hostile to protochronism, could not be disbanded purely and simply. The only thing that the officials could do was not to call its leadership Board. Yet how could the protochronists imagine that, in a single-party regime, there could be two professional guilds? And of which, only one could be the Union of Communist Writers? In the same logical, and not in the least political, order, this would have meant that in the Romania of 
the golden age, there was also a Union of Non-Communist Writers? Pushed from behind by the lack of political intelligence of the protochronists, Ceauşescu became, of course, without realising it, an ally of the liberal and pro-Western writers. In the wooden tongue of communism, Ceaușescu was what used to be called an objective ally, that is, imposed by the circumstances and without necessarily agreeing, rather on the contrary, with the role he played. After 1971, some of the communist intellectuals of Ivaşcu's generation had also become our objective allies. Left-leaning people, they had been marginalised following the veering of Ceauşescu-communism towards the nationalist right. The situation was extremely complicated. The party was trying, by all means, to preserve the image of ideological unity, although we could no longer speak of an ideology, and all the less so, of a monolithic one, which was the current expression. Censorship could no longer rely on a consistent and coherent ideology, like in the 1950s. Instead of imposing concepts, it was hunting for words. A censorship whose only criterion was of a lexical nature could only be contradictory and unpredictable. In the dogmatic decade, the demarcation line between what was allowed (and compulsory!) and what was banned was traced with an even hand. As the basic unity had vanished, no demarcation remained visible to the eye. Another thing worth mentioning, which was noticed by Paul Georgescu, was that there was a censorship without censors. Even before it was "disbanded" as an institution in 1977 (somewhat off the cuff, during an informal discussion between Ceauşescu and several writers, among whom Titus Popovici, who showed Ceauşescu's supreme arrogance of playfully deciding on matters of great importance for the country), censorship already had difficulties in recruiting and training its staff. The difficulties worsened after 1977, when the editors in chief and the clerks of the Ministry of Culture or the party apparatus took over its tasks: added to the lack of clear ideological criteria was the lack of coordination among the improvised censors, forced to act as they thought best and always fearing that they would be made accountable for their decisions.

A new and unsettling phenomenon for the cultural officialdom was, in the same period, the dissidence. Emerging in the Soviet Union at the same time with the Khrushchev-era liberalisation, the phenomenon is one linked to the ageing of the communist regimes, when the repression was dwindling in intensity. This 
loss of speed is evinced by all the dictatorships, but especially by the communist ones, not as an effect of a self-made strategy of ideological relaxation, but as a tactical necessity resulting from political and economic reasons. In yesterday's Soviet Union an in today's Arab countries, things are happening in the same way: it is not the regime which wants change and, if it implements it, it does not do so from conviction, but forced by reality, using it as a momentary tactic, not as a long-term strategy. Moreover, the regime is deceived by the illusion that the tactic will be efficient and it will be too late when it discovers that what was needed was a truly reforming strategy. Only that, in the case of totalitarianism, the reform leads to collapse. A classical case is that of Gorbachev's perestroika. The last Soviet tsar did not want to reform the system, but only to improve its functioning, in the conditions of an unprecedented crisis. $\mathrm{He}$ would admit it himself, one decade later, during a conference in Berlin, that he didn't know, even at the end of the 1980s, that the communist system could not be reformed without the risk of being destroyed. Ceaussescu had known it long before. That is why he refused any ideological and political compromise. The dissidents appeared as a result of this tactic that the regime was forced to adopt by the domestic crisis. At the height of Stalinism, they would have been simply shot. Brezhnev and Ceauşescu contended themselves to committing them to psychiatric wards or to staging them common-law trials and, when they saw no other solution, because the information was circulating differently than before, to have them expatriated. Sooner or later, it is this very circulation of information that will end the dictatorships. Marx said in the 19th century that the proletariat is the grave digger of capitalism. How much the world has changed, we can see from the fact that, in the 21st century, the grave digger of the dictatorships is no longer a social class, but information, that is, the internet.

The dissidents and the exiles were a great headache for Ceauşescu, but their role is not always correctly placed in the political equation of the last decades of communism. I have mentioned the criticism above, which I consider biased and unfounded, of those who refuse any political impact to the intellectuals of my generation, only because they preferred indirect means of action, like aestheticism. The choice of circumventing routes, when speaking of literature, not of militant action, means the belief that the goal of art, in general, can only be attained through indirect means, if 
we want to preserve its specificity. Which does not rule out possible political effects. The battle around protochronism, led with literary arguments and means, was a political battle. I have briefly described it and I think I have delivered my message. On the other hand, and from the very beginning, the dissidents' and the exiles' role was a political one, even if we consider the cultural dissidence. For this reason, the regime sought to repress it at any cost. The intellectual resistance seemed less alarming precisely because it was not perceived as being political. Since its childhood, the regime had the experience of the class enemy. The dissidents were the class enemies of the old age of communism. The writers who did not oppose it overtly, politically, were treated with prudence, because the regime was not fully realising the threat that they represented. It could not correctly appreciate the substance of the power of the powerless, as Havel called the power of the intellectuals. The value of the literature of the dissidents is beyond discussion. In general, the regime was not actually interested in the value, but in the public impact of literature, quite like, as a matter of fact, the public impact of any action. The dissidents' books were not published at home, which, in the eyes of the regime, deprived them of impact, with insignificant exceptions. Since the very beginning, the trips abroad, the contact with foreigners and the introduction of books and magazines in the country were a constant concern for the regime, even when it could not prevent them any longer. Most of the surveillance files were opened with the occasion of a trip abroad. It was the direct character of the contestation and not the dissidents' literature that was irritating the communist officialdom. Hence, the reactions. The literature published at home, in state-run publishing houses, read by many, relatively freely commented by critics and turned into a school curriculum subject was considered, despite the compromises and its Aesopic language, with much greater attention. It was supposed that its publication had the party's green light, so that these literary works had to be ideologically impeccable. All things considered, the lack of unmitigated political character made it less worrying, which proved to be a deadly error of appreciation for the regime. Censorship actually lacked convincing arguments in order to ban the publication and circulation of this literature, which was becoming less and less subservient to the party rigours. In the 1970s, a department of "Syntheses" was created besides the censorship proper, which re-read the already published books and 
operated changes. The cultural officialdom was taking precautionary measures, one would say, yet their outcome was not and for a long time the one expected. Even if they resorted to banning from signature some writers in the country (the dissidents, be they exiled or not, had no right of signature anyway), in the mid 1980s, the officialdom could not remove them from the textbooks and sometimes not even from the bookstores, because everyting had become chaotic and uncontrollable. An authoritarian regime which loses its ideological criteria also loses its authority. In the end, the Ceauşescu regime was only an empty shell. Beyond the material causes which had pushed it into this extreme situation, the moral contestation had played a role, and not in the least by a literature which, after 1965 , had regained, concomitantly with its value, also that dignity in the people's eyes, which gave it the strength to win the war with the official ideology, to re-establish the connection with the national tradition and with other literatures of the world. Communism was defeated not only by its own, inborn, flaws of a social and economic nature, which the Marxist ideology hid with a diabolical perversion, but also by the regained force of the written word. The writers are not only survivors, but also winners. At the peace negotiating table, they deserved to occupy a forefront place.

Nicolae Manolescu nasceu em 1939 e é crítico literário e historiador. É autor de mais de 40 títulos, especialmente nos domínios da crítica e da história literária. É professor da Universidade de Bucareste, Presidente da Uniáo de Escritores da Romênia e Embaixador da Romênia junto à UNESCO. 